\title{
Mesozoic and Tertiary Rocks near Elko, Nevada-Evidence for Jurassic to Eocene Folding and Low-Angle Faulting
}

\section{U.S. GEOLOGICAL SURVEY BULLETIN 1988-C}

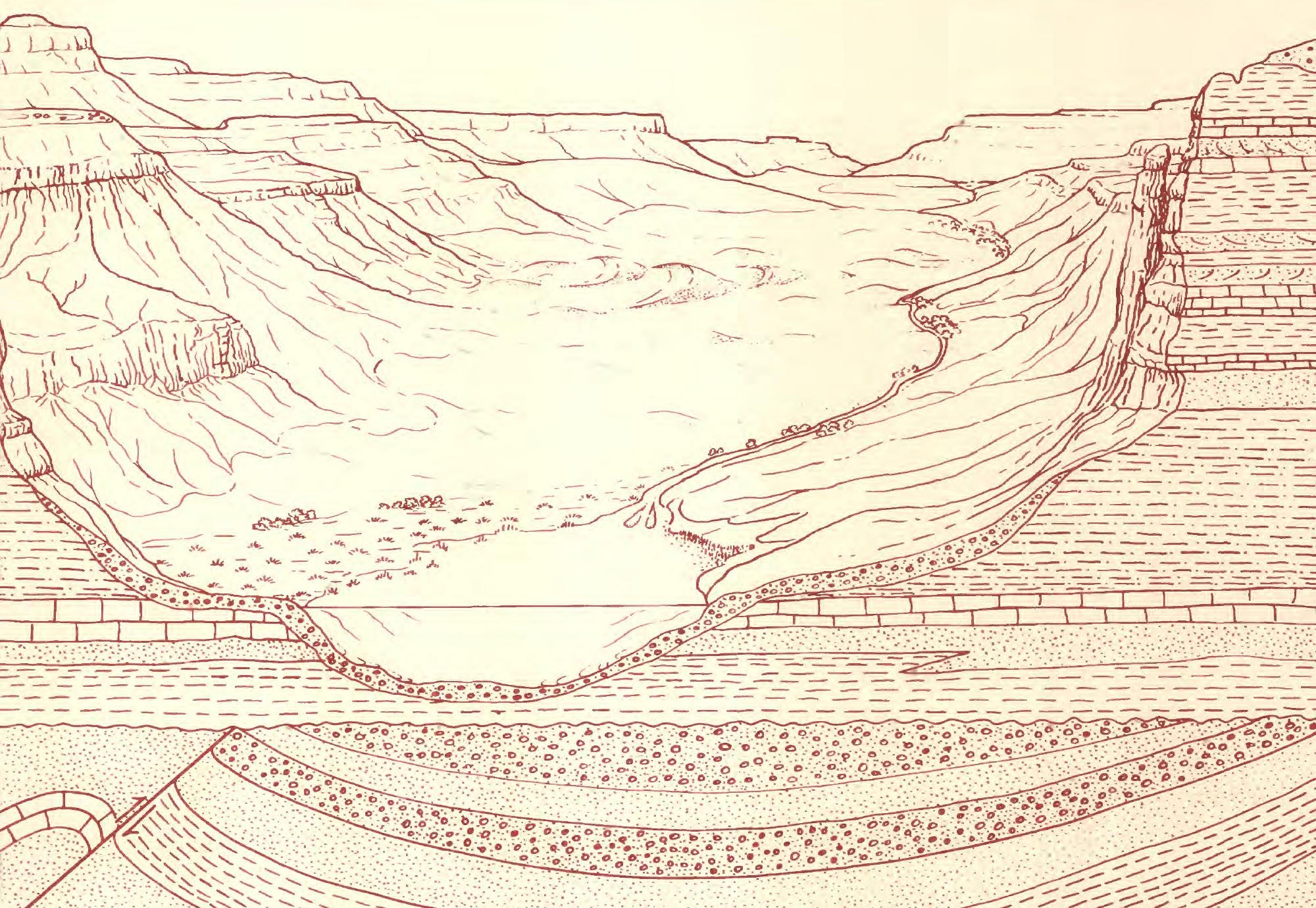




\section{AVAILABILITY OF BOOKS AND MAPS OF THE U.S. GEOLOGICAL SURVEY}

Instructions on ordering publications of the U.S. Geological Survey, along with the last offerings, are given in the current-year issues of the monthly catalog "New Publications of the U.S. Geological Survey." Prices of available U.S. Geological Survey publications released prior to the current year are listed in the most recent annual "Price and Availability List." Publications that are listed in various U.S. Geological Survey catalogs (see back inside cover) but not listed in the most recent annual "Price and Availability List" are no longer available.

Prices of reports released to the open files are given in the listing "U.S. Geological Survey Open-File Reports," updated monthly, which is for sale in microfiche from the U.S. Geological Survey Books and Open-File Reports Sales, Box 25286, Denver, CO 80225.

Order U.S. Geological Survey publications by mail or over the counter from the offices given below.

\section{BY MAIL}

\section{Books}

Professional Papers, Bulletins, Water-Supply Papers, Techniques of Water-Resources Investigations, Circulars, publications of general interest (such as leaflets, pamphlets, booklets), single copies of periodicals (Earthquakes \& Volcanoes, Preliminary Determination of Epicenters), and some miscellaneous reports, including some of the foregoing series that have gone out of print at the Superintendent of Documents, are obtainable by mail from

\section{U.S. Geological Survey, Books and Open-File Report Sales Box 25286 \\ Denver, CO 80225}

Subscriptions to periodicals (Earthquakes \& Volcanoes and Preliminary Determination of Epicenters) can be obtained ONLY from

\section{Superintendent of Documents \\ U.S. Government Printing Office Washington, DC 20402}

(Check or money order must be payable to Superintendent of Documents.)

Maps

For maps, address mail order to

\section{U.S. Geological Survey, Map Sales Box 25286 Denver, CO 80225}

Residents of Alaska may order maps from

$$
\begin{aligned}
& \text { U.S. Geological Survey, Map Sales } \\
& 101 \text { Twelfth Ave., Box } 12 \\
& \text { Fairbanks, AK } 99701
\end{aligned}
$$

\section{OVER THE COUNTER}

\section{Books}

Books of the U.S. Geological Survey are available over the counter at the following U.S. Geological Survey offices, all of which are authorized agents of the Superintendent of Documents.

- ANCHORAGE, Alaska-4230 University Dr., Rm. 101

- ANCHORAGE, Alaska-605 West 4th Ave., Rm G-84

- DENVER, Colorado-Federal Bldg., Rm. 169, 1961 Stout St.

- LAKEWOOD, Colorado-Federal Center, Bldg. 810

- MENLO PARK, California-Bldg. 3, Rm. 3128, 345 Middlefield Rd.

- RESTON, Virginia-National Center, Rm. 1C402, 12201 Sunrise Valley Dr.

- SALT LAKE CITY, Utah-Federal Bldg., Rm. 8105, 125 South State St.

- SPOKANE, Washington-U.S. Courthouse, Rm. 678, West 920 Riverside Ave.

- WASHINGTON, D.C.-U.S. Department of the Interior Bldg., Rm. 2650, 1849 C St., NW.

\section{Maps}

Maps may be purchased over the counter at the U.S. Geological Survey offices where books are sold (all addresses in above list) and at the following Geological Survey offices:

- ROLLA, Missouri-1400 Independence Rd.

- FAIRBANKS, Alaska-New Federal Building, 101 Twelfth Ave. 
Chapter C

\section{Mesozoic and Tertiary Rocks near Elko, Nevada-Evidence for Jurassic to Eocene Folding and Low-Angle Faulting}

By KEITH B. KETNER and ANDREW G. ALPHA

A multidisciplinary approach to research studies of sedimentary rocks and their constituents and the evolution of sedimentary basins, both ancient and modern

U.S. GEOLOGICAL SURVEY BULLETIN 1988

EVOLUTION OF SEDIMENTARY BASINS-EASTERN GREAT BASIN

HARRY E. COOK and CHRISTOPHER J. POTTER, Project Coordinators 


\title{
U.S. DEPARTMENT OF THE INTERIOR
}

MANUEL LUJAN, JR., Secretary

\author{
U.S. GEOLOGICAL SURVEY
}

Dallas L. Peck, Director

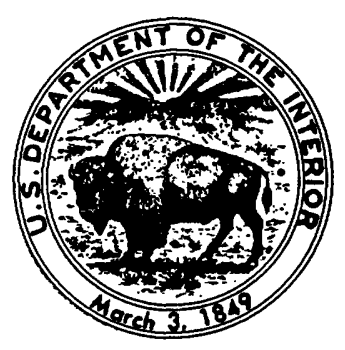

Any use of trade, product, or firm names in this publication is for descriptive purposes only and does not imply endorsement by the U. S. Government

UNITED STATES GOVERNMENT PRINTING OFFICE: 1992

For sale by

Book and Open-File Report Sales

U.S. Geological Survey

Federal Center, Box 25286

Denver, CO 80225

Library of Congress Cataloging-in-Publication Data

Ketner, Keith Brindley, 1921-

Mesozoic and Tertiary rocks near Elko, Nevada--evidence for Jurassic to Eocene

folding and low-angle faulting / by Keith B. Ketner and Andrew G. Alpha.

p. cm. - (U.S. Geological Survey bulletin ; 1988-C)

(Evolution of sedimentary basins-Eastern Great Basin ; ch. C.)

Includes bibliographical references.

1. Folds (Geology)-Nevada-Elko Region. 2. Geology Stratigraphic-

Mesozoic. 3. Geology, Stratigraphic-Tertiary. 4. Geology-Nevada-Elko

Region. I. Alpha, Andrew G. II. Series. III. Series: Evolution of sedimentary

basins-Eastern Great Basin ; ch. C.

QE75.B9 no. 1988-C

[QE606.5.N3]

557.3 s--dc20

[551.8'7’0979316] 


\title{
CONTENTS
}

\author{
Abstract C1 \\ Introduction $\mathbf{C 1}$ \\ Stratigraphy of Mesozoic and Paleogene rocks $\quad$ C1 \\ Lower Triassic sequence of the northern Adobe Range C1 \\ Upper Jurassic sequence of the northern Cortez Mountains C2 \\ Cretaceous Newark Canyon Formation of the northern Cortez Mountains \\ and Piñon Range C3 \\ Uppermost Cretaceous to Eocene conglomerate C3 \\ Eocene Elko Formation $\quad$ C3 \\ Eocene rhyodacite of Elko Mountain C5 \\ Eocene and Oligocene Indian Well Formation C6 \\ Deformation of Mesozoic and Eocene age C9 \\ Northern Adobe Range $\quad$ C10 \\ Peko Hills C10 \\ Northern Cortez Mountains $\quad$ C10 \\ Piñon Range C10 \\ Elko Hills C11 \\ Folds and low-angle faults in the Elko area: Contractional or extensional? C11 \\ Comparison with the Idaho-Wyoming-Utah Thrust Belt $\quad \mathbf{C 1 2}$ \\ References cited $\quad \mathbf{C 1 2}$
}

\section{FIGURES}

1. Map of Elko area, northeastern Nevada, showing trends of folds and attitudes of steeply dipping beds in Big Pole Formation

C2

2. Map and cross section in Coal Mine Basin area, northern Adobe Range, showing generalized geology and structural relations

3. Map of part of northern Cortez Mountains showing generalized geology and structural features

C6

4. Map of Emigrant Spring area in northern Piñon Range showing generalized geology and structural features

5. Map and cross sections of Elko Hills showing generalized geology and structural features $\quad$ C8 


\title{
Mesozoic and Tertiary Rocks near Elko, Nevada-Evidence for Jurassic to Eocene Folding and Low-Angle Faulting
}

\author{
By Keith B. Ketner and Andrew G. Alpha
}

\begin{abstract}
Post-Early Triassic, large-scale folds broken by low-angle faults form a family of north- to northeast-trending structures in the Elko, Nevada, area. Some folds can be dated only as post-Early Triassic and pre-Eocene; others are of Eocene age. In the Adobe Range Triassic and older units are tightly folded, overridden by Permian to Ordovician strata and overlain unconformably by Eocene rocks. In the Peko Hills Paleozoic strata as young as mid-Permian are also tightly folded and overridden by Triassic to Mississippian rocks. In the Cortez Mountains steeply dipping Upper Jurassic volcaniclastic rocks are overlain by mid-Cretaceous strata that dip gently in the opposite direction suggesting latest Jurassic to early Cretaceous deformation. In the Piñon Range Eocene and Mississippian rocks are folded to form a syncline that plunges below relatively undeformed latest Eocene and Oligocene volcanic strata. In the Elko Hills Eocene and late Paleozoic rocks are folded and overridden discordantly by late Paleozoic strata. Characteristic features of highly extended terranes, such as extremely rotated fault blocks, younger over older low-angle faults with omission of strata, and extremely attenuated strata, are scarce in the Elko area. In contrast, large-scale southeastverging folds broken by older over younger faults that involve juxtaposition of contrasting facies are the rule and are interpreted to indicate at least intermittently contractional conditions beginning in the Late Jurassic and ending in the late Eocene.
\end{abstract}

\section{INTRODUCTION}

Intensive upper crustal folding and low-angle faulting of post-Paleozoic, mainly Mesozoic, age throughout northeastern Nevada are well documented (Ketner and Smith, 1974,

Manuscript approved for publication January 31, 1992.
1982; Coats and Riva, 1983; Ketner, 1984, 1987, 1990; Clark, 1985; Ehman, 1985; Coats, 1987; Little, 1987; Ketner and Evans, 1988; Ketner and Ross, 1990; Thorman and others, 1991). Some evidence of Paleogene folding was described previously (Smith and Ketner, 1976) but has received little attention. In this report we update the Mesozoic and Paleogene stratigraphic sequence, review some of the published evidence for post-Paleozoic folding and lowangle faulting in the Elko area, and attempt to demonstrate that post-Paleozoic upper crust contractional tectonism in the Elko area began as early as the Late Jurassic and ended in the late Eocene.

Acknowledgments. - We benefitted from comments by Harald D. Drewes, Thomas D. Fouch, Richard K. Hose, David M. Miller, Lucian B. Platt, Charles A. Sandberg, Arthur W. Snoke, and Robert C. Speed. However, the authors are solely responsible for the interpretations expressed herein.

\section{STRATIGRAPHY OF MESOZOIC AND PALEOGENE ROCKS}

Mesozoic and Paleogene strata in the Elko area include detrital sedimentary and volcanic deposits whose nature and ages are useful for dating the tectonic events in the area, and they are therefore discussed in detail as a necessary preliminary to a discussion of structure.

\section{Lower Triassic Sequence of the Northern Adobe Range}

Lower Triassic rocks of the northern Adobe Range (figs. $1,2)$ are thinly laminated limy shale and argillaceous 
limestone representing distal turbidite deposition, but they also include sporadic debris flows and isolated large blocks derived mainly from the mid-Permian Gerster Limestone (Ketner and Ross, 1990). The Gerster is a parautochthonous, abundantly fossiliferous, shallow-marine shelf unit of the Nevada-Utah border area. Although the Triassic sequence is allochthonous in the Adobe Range, the presence of coarse

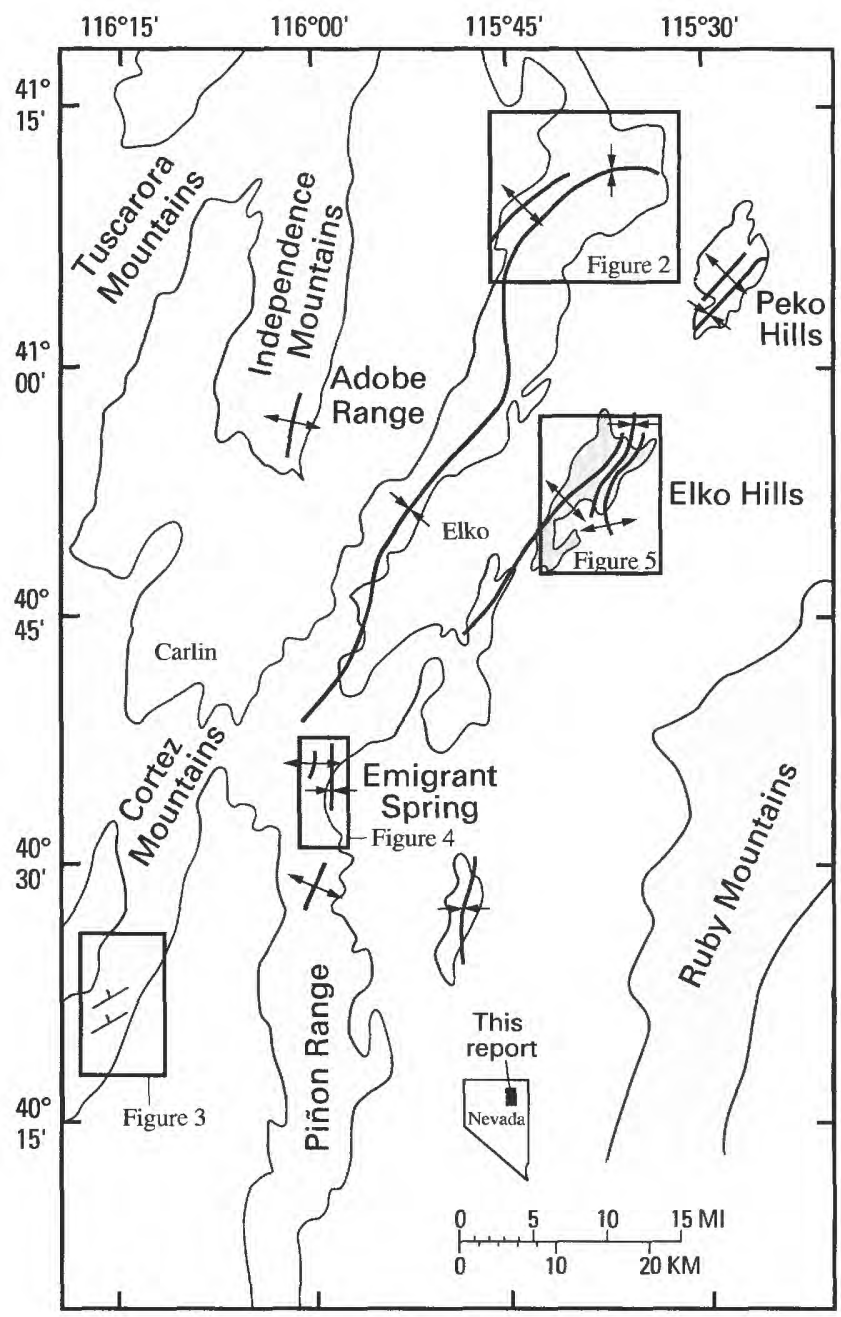

EXPLANATION

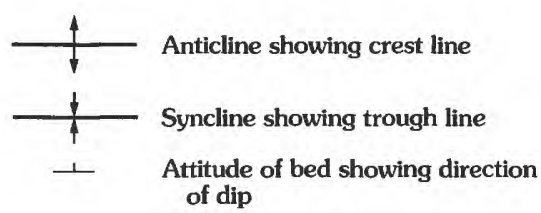

Figure 1. Map of Elko area, northeastern Nevada, showing trends of folds and, in Cortez Mountains, attitudes of steeply dipping beds in Jurassic Big Pole Formation. Locations of figures 2-5 also shown. debris flows composed of Gerster-derived detritus indicates that the sequence is indigenous to the northeastern Nevada area. Presence of the easterly derived olistostromes also indicates that the Triassic sediments were deposited on, or at the foot of, a slope that probably faced generally westward or northwestward away from the probable source of debris. The age of the Adobe Range Triassic sequence was determined to be Smithian (mid-Early Triassic) on the basis of its ammonoid fauna (N.J. Silberling, U.S. Geological Survey, written commun., 1967). The sequence has also yielded Triassic conodonts. Triassic rocks occupy the center of the Adobe Range Syncline. If younger strata ever had been deposited on the Triassic rocks prior to folding, they are now entirely absent. The same formation at other localities in northeastern Nevada has yielded Griesbachian (lowest Triassic) and Spathian (uppermost Lower Triassic) conodonts (Bruce Wardlaw, U.S. Geological Survey, oral commun., 1990). The formation therefore originally probably spanned the entire Lower Triassic interval.

\section{Upper Jurassic Sequence of the Northern Cortez Mountains}

An area of at least $150 \mathrm{mi}^{2}\left(388 \mathrm{~km}^{2}\right)$ in the northern Cortez Mountains (fig. 3) is underlain by extrusive rocks and volcaniclastic sedimentary rocks assigned to the Jurassic Pony Trail Group and by numerous stocks of Jurassic age (Muffler, 1964; Smith and Ketner, 1976). The Pony Trail is composed of three formations separated by unconformities (in ascending order): the Big Pole Formation, the Sod House Tuff, and the Frenchie Creek Rhyolite. The Big Pole consists mostly of volcaniclastic sedimentary rocks, tuffs, and rhyodacitic flows "deposited in a rapidly subsiding basin in a tectonically active area" (Muffler, 1964, p. 25). Whether the basin was marine or continental has not been determined. The Sod House Tuff, the Frenchie Creek Rhyolite, and clasts of the Big Pole Formation are of rhyolitic to dacitic composition. The age of the Frenchie Creek Rhyolite, the youngest unit of the Pony Trail Group, as determined by R.L. Armstrong (Smith and Ketner, 1976), is 151 \pm 3 Ma (K-Ar, biotite). Several granitic plutons intrude Paleozoic rocks in the area and the Pony Trail Group. They range in composition from alaskite to diorite, but predominant rock types are granodiorite and monzonite. Radiometric ages, determined by R.L. Armstrong (1963) and reported by Muffler (1964), are granodiorite $150-8+23 \mathrm{Ma}(\mathrm{K}-\mathrm{Ar}$, hornblende), alaskite $125-6+19$ and $145-7+22 \mathrm{Ma}$ (K-Ar, hornblende). The age of a monzonite stock, determined by G.H. Curtis (Gilluly and Masursky, 1965), is $151 \mathrm{Ma}$ (K-Ar, biotite). The deformed Pony Trail Group is overlain unconformably by gently dipping lower Upper Cretaceous beds of the Newark Canyon Formation (fig. 3). 


\section{Cretaceous Newark Canyon Formation of the Northern Cortez Mountains and Piñon Range}

Lake and alluvial deposits of the Cretaceous Newark Canyon Formation cover a large area in the Cortez Mountains, and scattered erosional remnants indicate that the formation originally covered a large area in the southern Piñon Range (Smith and Ketner, 1978). Cretaceous beds in the Cortez Mountains consist of coarse heterogeneous conglomerate, sandstone, and mudstone, whereas in the Piñon Range they consist mostly of shale and sandstone. Most of the larger clasts in the conglomerate were derived from local formations of Mississippian to Jurassic age (Biglow, 1986), but some were derived from lower Paleozoic units.

Exposures of the Newark Canyon Formation are widely scattered elsewhere in northeastern and central Nevada. The formation typically includes coarse, locally derived conglomerate and attains thicknesses of $1,800 \mathrm{ft}(549 \mathrm{~m})$ in the Newark Canyon area near Eureka (Nolan and others, 1956) and more than $2,500 \mathrm{ft}(762 \mathrm{~m})$ in the Cortez Mountains. Its age, based on a fauna of fish, dinosaurs, plants, and ostracodes, is Early and Late Cretaceous and possibly Paleocene. Evidence from the Newark Canyon area near Eureka, Nevada, indicates a late Early Cretaceous age for the formation, and evidence from the Cortez Mountains indicates an early Late Cretaceous age. An Early Cretaceous age of the ostracode fauna from younger beds at the principal Piñon Range locality has been questioned by Fouch and others (1979) and the fauna tentatively assigned a Late Cretaceous and (or) Paleocene age, but the original determination of Early Cretaceous for older beds at that locality (I.G. Sohn in Smith and Ketner, 1976, p. B13) has not been questioned.

\section{Uppermost Cretaceous to Eocene Conglomerate}

Tracts of generally poorly dated and unnamed conglomeratic lake and lake-margin sequences are widespread in the Elko area. The thickness of one tract in the Piñon Range was estimated to be more than $2,000 \mathrm{ft}(610 \mathrm{~m})$ (Smith and Ketner, 1976). The stratigraphic positions of these sequences, their lack of tuffaceous beds, and their heterogeneous compositions, which commonly include clasts of Permian rocks, suggest a Cretaceous to earliest Tertiary age and probable stratigraphic equivalence to the Sheep Pass Formation of east-central Nevada (Fouch and others, 1979). Ostracodes and charophytes collected from one of these tracts between the Elko Hills and the Piñon Range indicate an age within the latest Cretaceous to Eocene interval (I.G. Sohn and R.E. Peck in Smith and Ketner, 1976). These conglomeratic units could be assigned either to the Newark Canyon Formation or to the basal part of the Elko Formation with equal validity, but they are here left unassigned pending better dating.

\section{Eocene Elko Formation}

Eocene lake beds and associated alluvial deposits are here divided into three units (in ascending order): basal conglomeratic unit, cherty limestone, and shaly unit. The basal conglomeratic unit lies unconformably on Ordovician to Triassic strata or, rarely, on Cretaceous rocks. This conglomeratic unit, consisting of beds of alluvial sand, pebbles, and cobbles, grades laterally into fine-grained lake sediments. The lithic composition of the clasts generally reflects that of the underlying formations. Sandy beds display strong crossbedding and, in places, are convoluted as if deformed by swift currents. Sorting of clasts is poor and degree of rounding is varied. In some exposures the conglomeratic unit encloses beds of rhyolitic tuff.

Commonly overlying the basal conglomeratic unit is a thick sequence of argillaceous and tuffaceous lake limestone that generally contains variously colored replacement chert nodules. This unit is widespread in the Piñon Range-Elko Hills area (figs. 4,5 ) but absent from the northern Adobe Range.

Next above is an extremely varied sequence characteristically shaly and so easily weathered that outcrops are scarce. This uppermost unit consists of shale, kerogenous oil shale, claystone, siltstone, cherty limestone, dolomite, sandstone, conglomerate, and, rarely, tuff. The lithic composition varies widely from place to place and reflects varied depositional conditions in a lake environment.

The term Elko Formation has been used inconsistently by different authors and applied inconsistently to exposures in different areas. To avoid further confusion we here propose a revised definition. The name Elko Formation has been applied either to the upper unit of the tripartite Eocene sequence here described (Solomon and others, 1979) or to the upper two units (Smith and Ketner, 1976; Server and Solomon, 1983). In this report the three units commonly comprising the concordant Eocene sequence-basal conglomeratic unit, cherty limestone, and shaly unit-are regarded as the informally designated lower, middle, and upper members of the Elko Formation.

This usage is justified as follows. The type section of the Elko Formation in the Piñon Range as originally mapped and described by Smith and Ketner $(1976$, p. B19; 1978) and later by Server and Solomon (1983) explicitly includes the cherty limestone unit, although in adjacent areas the cherty limestone was mapped as a separate unnamed unit (Smith and Ketner, 1976, 1978). The basal conglomeratic unit is discontinuous stratigraphically below limestone beds in the type section but was not originally recognized as Tertiary 

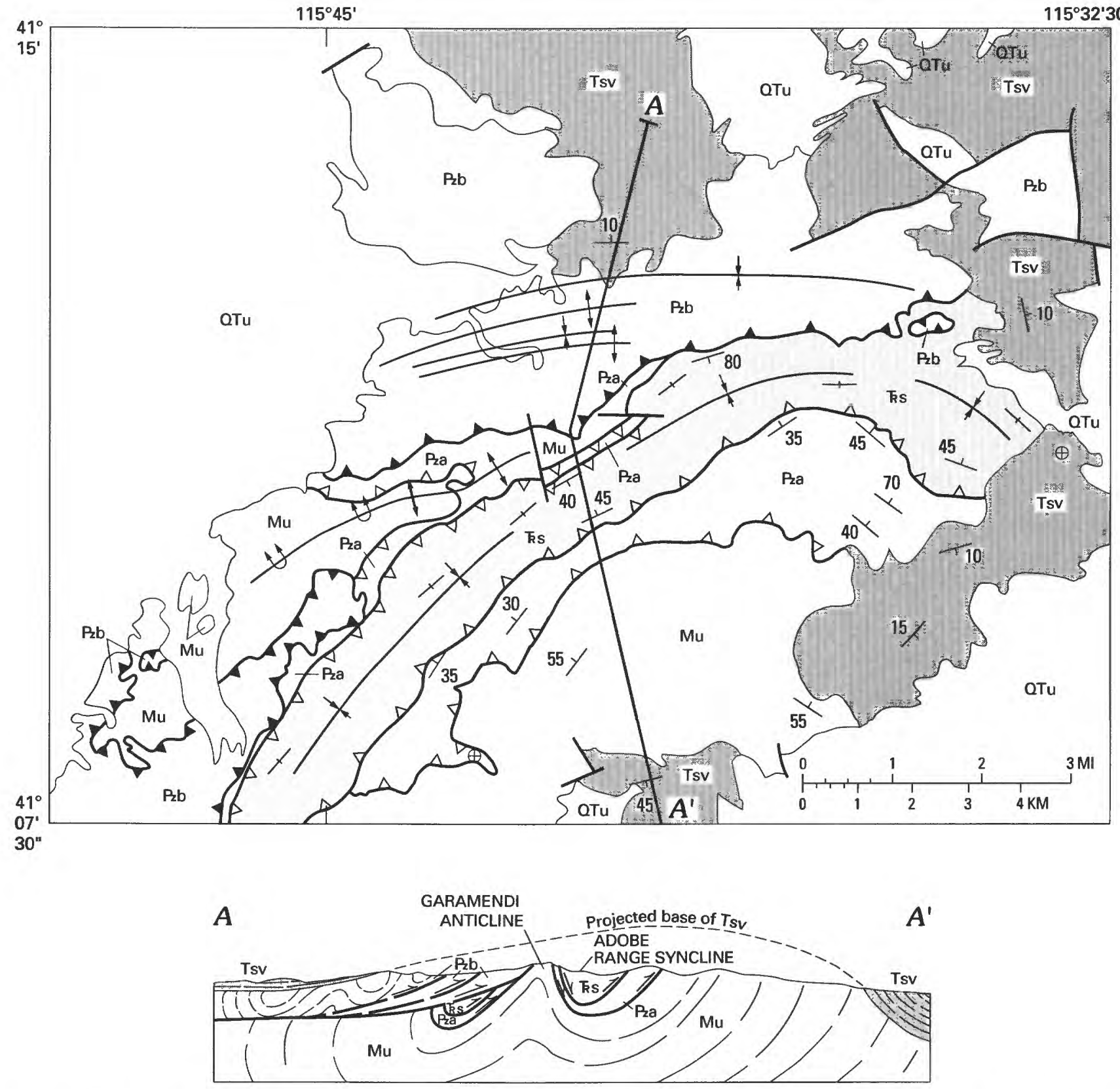

Figure 2 (above and facing page). Map and cross section in Coal Mine Basin area, northern Adobe Range, northeastern Nevada. Plates of lower Paleozoic, Permian, and Triassic rocks were emplaced over undeformed Mississippian and Pennsylvanian units on low-angle faults. This tectonic stack was then folded to form Adobe Range Syncline and Garamendi Anticline. Next, lower Paleozoic western facies rocks (Roberts Mountains allochthon) and slices of local Permian and Triassic rocks were thrust over these folds. Finally, the Eocene Elko Formation was deposited with profound unconformity on the highly deformed units and was itself mildly deformed. Location of map area shown on figure 1. Modified from Ketner and Ross (1990). 


\section{EXPLANATION}

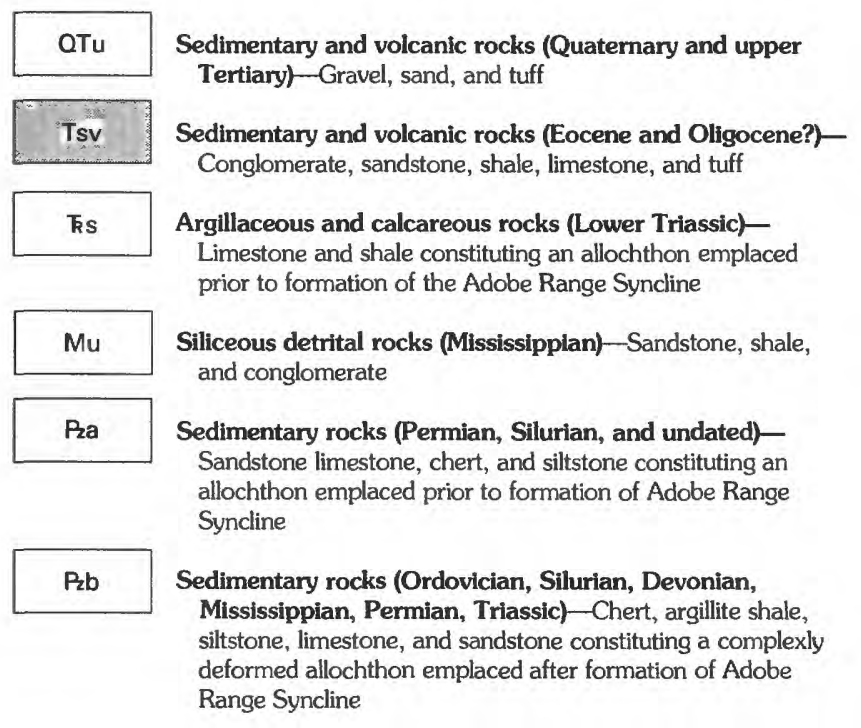

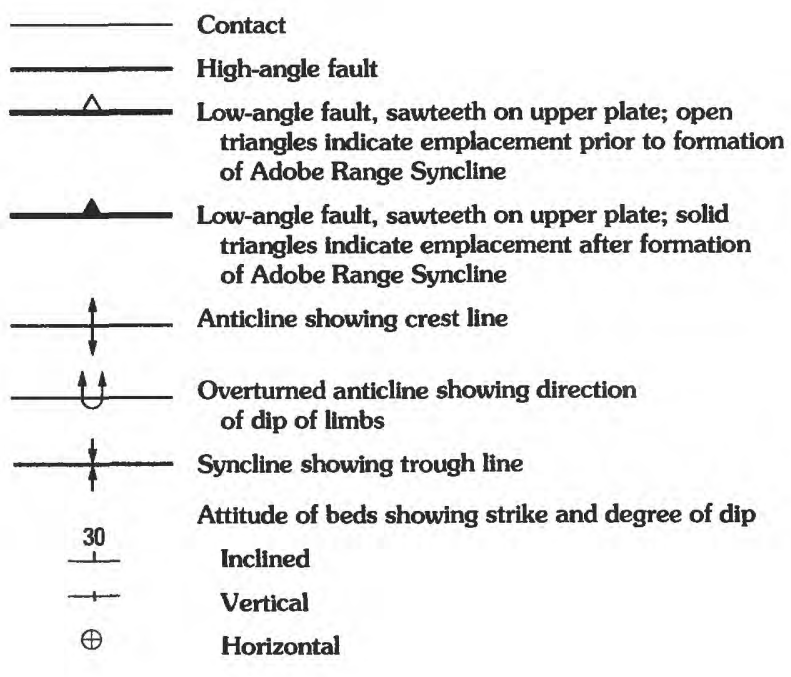

as Eocene and Oligocene(?) (Smith and Ketner, 1976; Solomon and others, 1979) because a tuff bed near the middle of the type section was dated radiometrically at $38.6 \pm 1.2$ $\mathrm{Ma}$, approximately on the Eocene-Oligocene boundary as formerly determined. Adjustment of the Eocene-Oligocene boundary from an indefinite point between 37 and $38 \mathrm{Ma}$ (Harland and others, 1964) to $35.4 \mathrm{Ma}$ (Harland and others, 1990) has eliminated the necessity for specifying a possible extension of the age of the formation into the Oligocene. Moreover, the Indian Well Formation, which unconformably overlies the Elko Formation, was dated as old as 37.6 Ma (Smith and Ketner, 1976) and is therefore now partly Eocene.

\section{Eocene Rhyodacite of Elko Mountain}

On Elko Mountain, the highest of the Elko Hills, the Elko Formation partly overlies, and partly merges laterally with, an altered extrusive rhyodacite sequence herein called the rhyodacite of Elko Mountain. This unit is almost completely altered hydrothermally to kaolinite and quartz. The rhyodacite of Elko Mountain has been misidentified both as an intrusive rock (Stewart and Carlson, 1978; Jaeger, 1987) and as the Jurassic Frenchie Creek Rhyolite (Coats, 1987). However, the rhyodacite sequence sporadically includes agglomerate, tuff, flow rocks with polygonal shrinkage joints, and interlayered conglomerate, sandstone, shale, and coal. Interbedded stratigraphic relations with the Eocene Elko Formation and a fission track age of $39.5 \pm 0.7 \mathrm{Ma}$ on apatite from a vitrophyre in the middle part of the sequence (R.A. Zimmerman, U.S. Geological Survey, written commun., 1987) indicate that the rhyodacite of Elko Mountain is Eocene in age. Unnamed rhyodacitic ignimbrites widely exposed in northeastern Nevada range from 42.5 to $39.3 \mathrm{Ma}$ in age (Coats, 


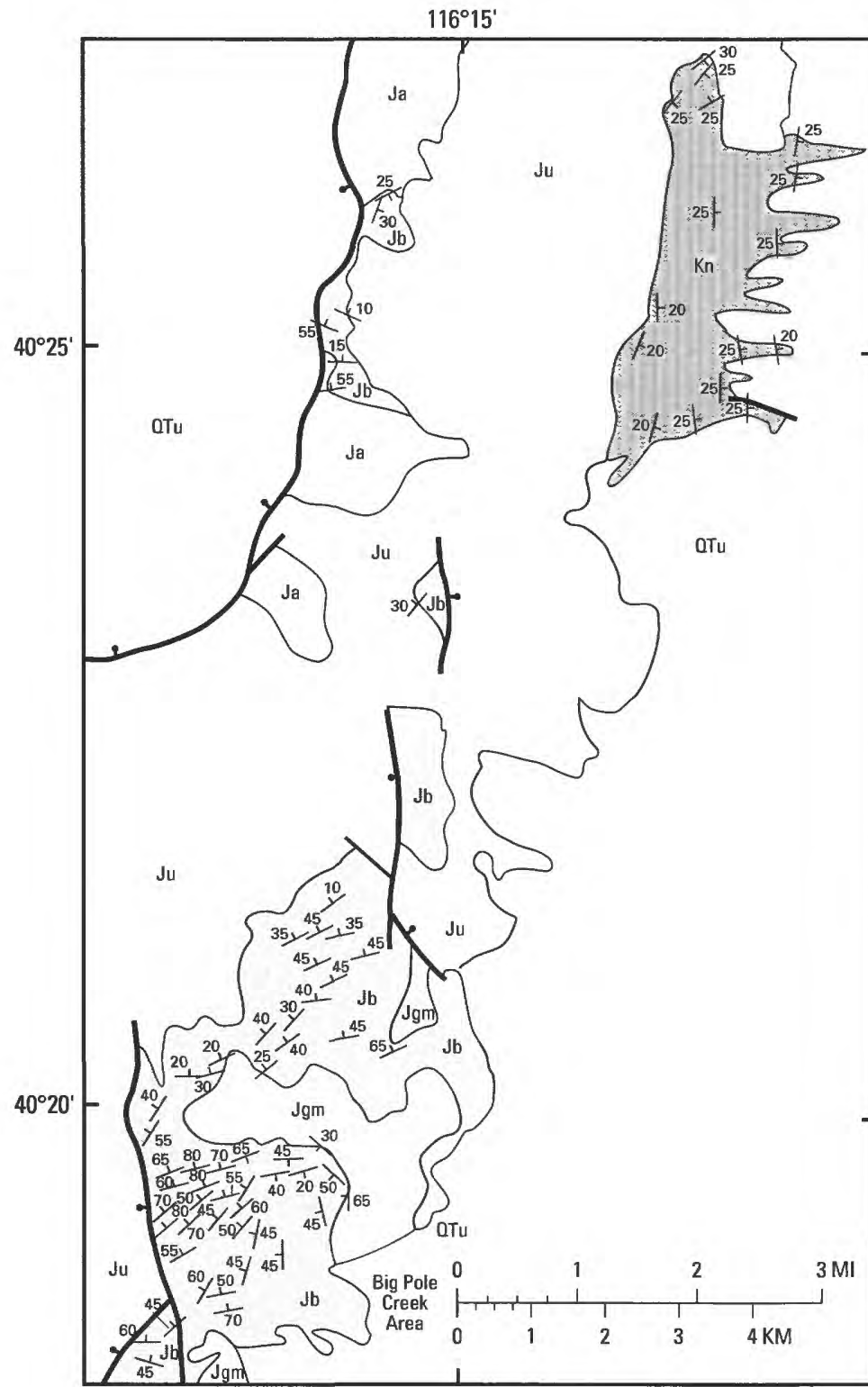

EXPLANATION

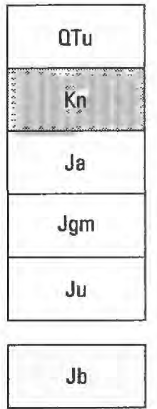

Alluvium and colluvium (Quaternary and Tertiary)-Gravel and sand

Newark Canyon Formation (Cretaceous)Conglomerate, sandstone and mudstone

Alaskite (Late Jurassic)-Stocks of quartz-rich granitic rock

Granodiorite and monzonite (Late Jurassic)Large stock

Frenchie Creek Rhyolite (Upper Jurassic) and Sod House Tuff (Upper? Jurassic)Tuff and rhyolite flow rocks

Big Pole Formation (Upper? Jurassic)volcaniclastic, conglomeratic sedimentary rocks, tuff, and flow rocks

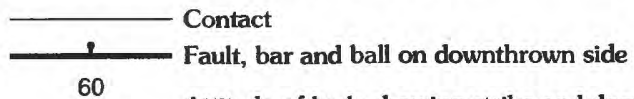

60

Attitude of beds showing strike and degree of dip

Figure 3. Map of part of northern Cortez Mountains, northeastern Nevada, showing contrast between steep dips of Late(?) Jurassic Big Pole Formation and gentle dips of Cretaceous Newark Canyon Formation. Location of map area shown on figure 1. Modified from Muffler (1964) and Smith and Ketner (1978).

1987) and are therefore partly correlative with the rhyodacite of Elko Mountain.

\section{Eocene and Oligocene Indian Well Formation}

The Indian Well Formation, which crops out widely between the Elko Hills and the Cortez Mountains and probably in the northern Adobe Range, is composed primarily of coarse volcaniclastic sedimentary rocks, agglomerate, flow rocks, and both welded and nonwelded tuff. Its composition is mainly rhyolite, but locally it includes andesite. The
Indian Well Formation overlies the Elko Formation unconformably throughout the Elko area. In several places between the Elko Hills and the Piñon Range it overlies preTertiary rocks as old as Devonian. Although the contact between the Elko and Indian Well Formations is poorly exposed, map patterns (as in fig. 4) indicate that the unconformity is angular and that the Indian Well is generally much less deformed than the Elko Formation. Seven radiometric ages (Smith and Ketner, 1976; Solomon and others, 1979) indicate that the Indian Well ranges in age from latest Eocene to late Oligocene on the basis of a 35.4-Ma date for the Eocene-Oligocene boundary. 


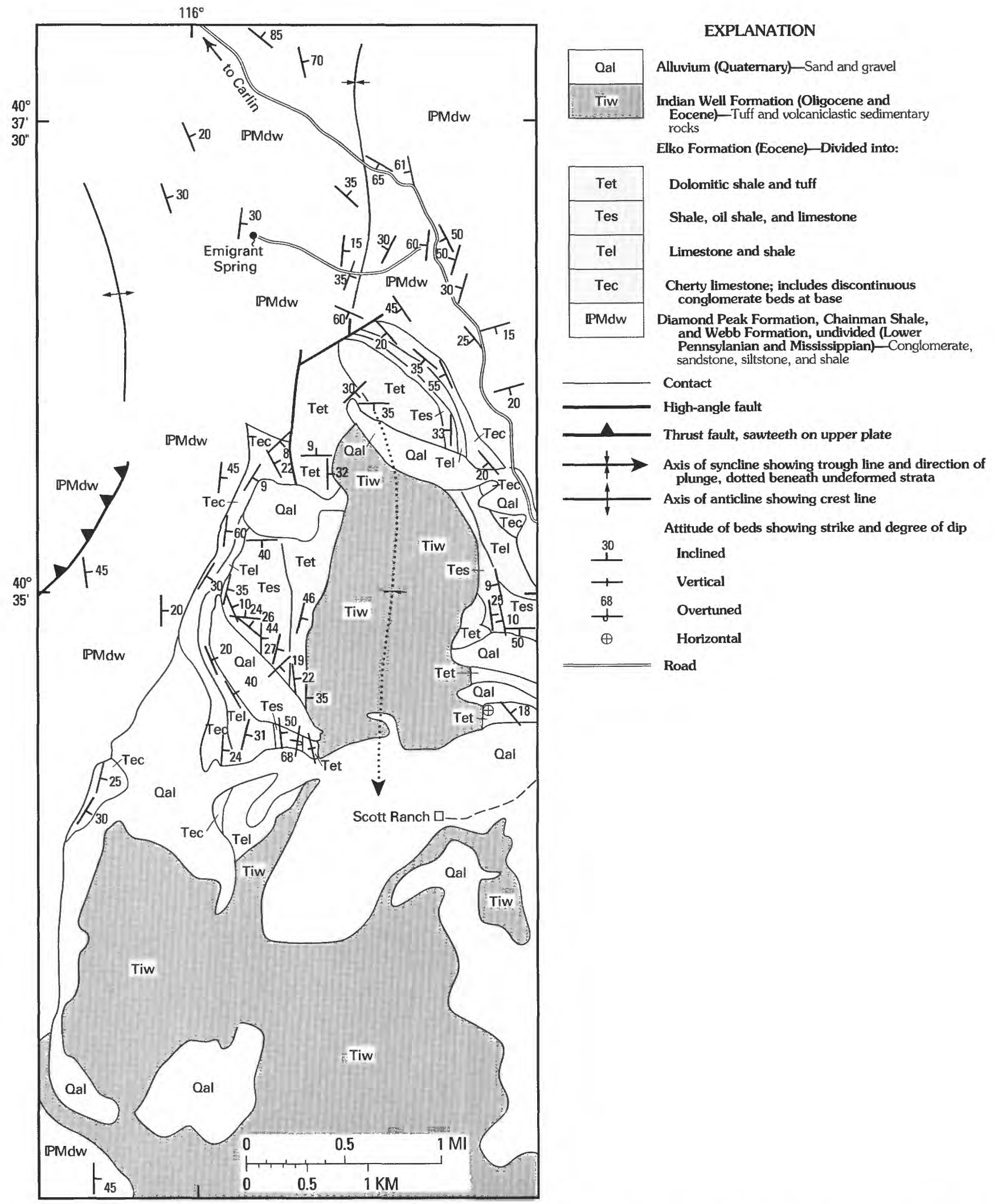

Figure 4. Map of Emigrant Spring area in northern Piñon Range, northeastern Nevada, showing axis of east-verging Emigrant Spring Syncline, axis of an adjacent subparallel anticline, and a minor thrust fault. Mississippian formations and Eocene Elko Formation are folded, but uppermost Eocene and Oligocene Indian Well Formation is undeformed and Emigrant Spring Syncline plunges southward beneath it. Location of map area shown on figure 1. Modified from Smith and Ketner (1978) and Server and Solomon (1983). 


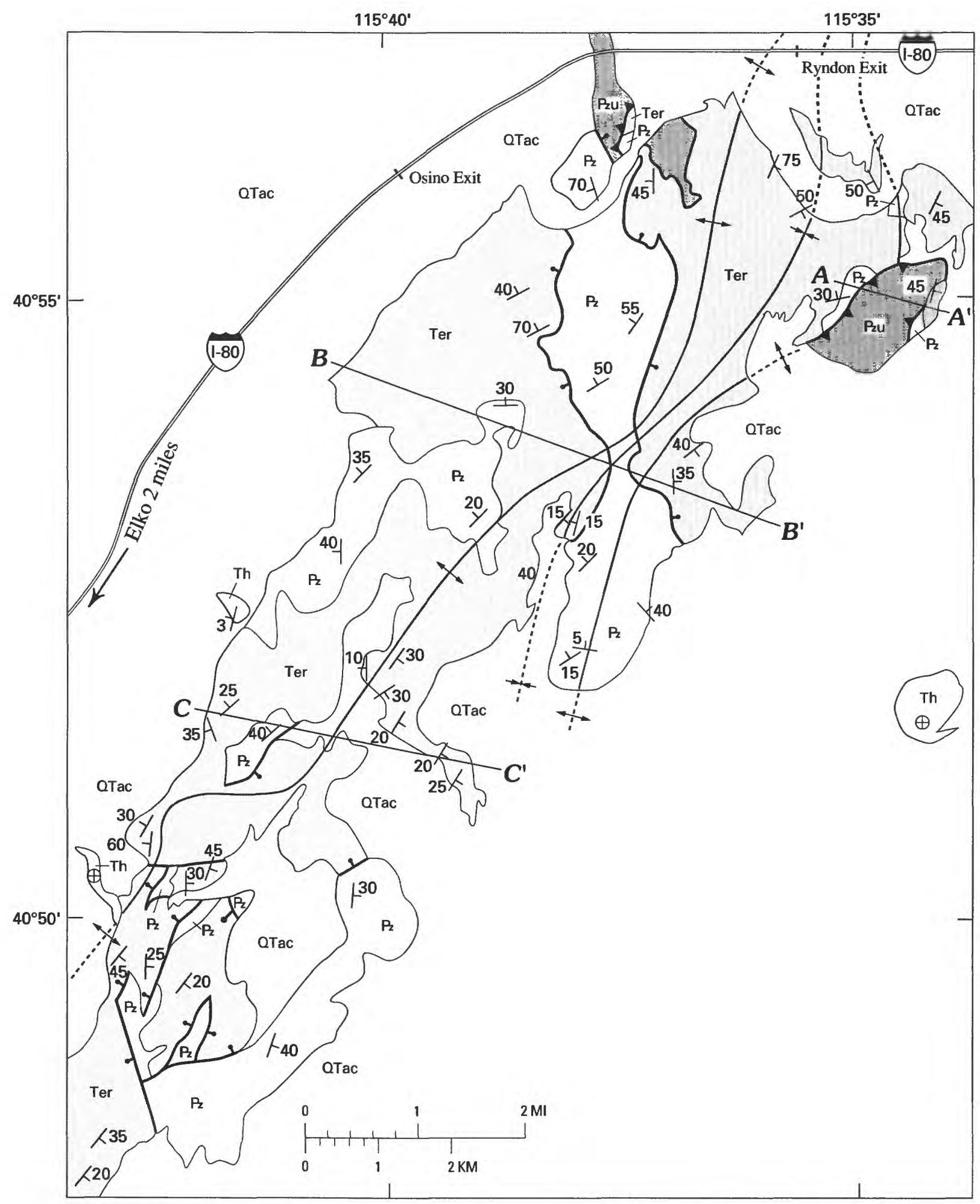

Figure 5 (above and facing page). Simplified map and cross sections of the Elko Hills, northeastern Nevada. Permian to Mississippian and Tertiary strata were folded and overridden by plates of Pennsylvanian to Mississippian rocks. Horizontal scale for cross sections differs from map scale. Location of map area shown on figure 1. Modified from Ketner (1990). 

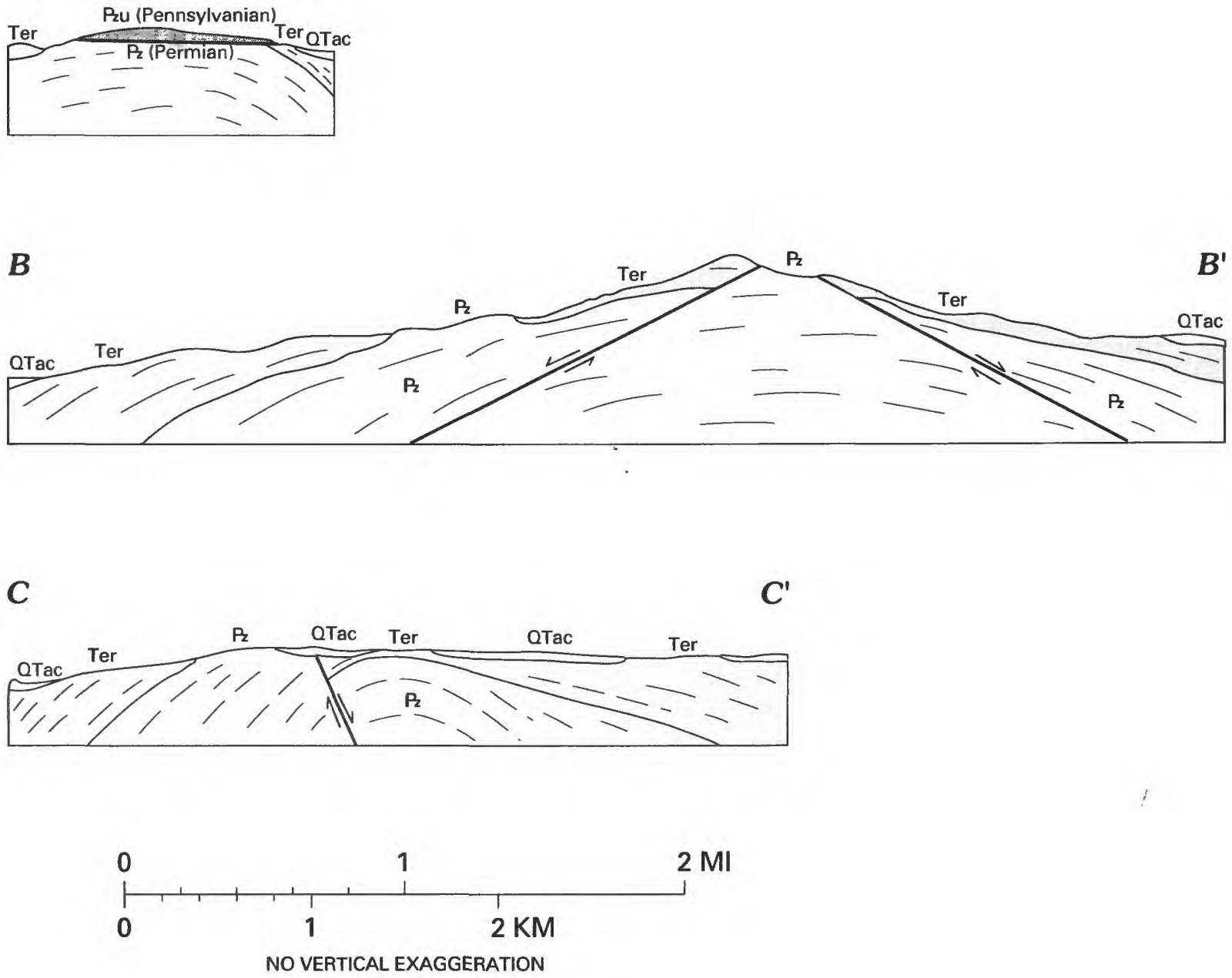

\section{EXPLANATION}

\begin{tabular}{|c|}
\hline Qtac \\
\hline Th \\
\hline Ter \\
\hline
\end{tabular}

$\mathrm{B}_{2}$

$\mathrm{PzU}_{\mathrm{U}}$
Alluvium and colluvium (Quaternary and upper Tertiary) - Sand, gravel, and volcanic ash

Humboldt Formation (Miocene)-Alluvial sand and gravel, volcanic ash, and lake deposits

Elko Formation and rhyodacite of Elko Mountain (Eocene)-Lake deposits consisting of conglomerate, limestone, siltstone, shale, oil shale, rhyodacitic flow rocks, agglomerate, and tuff

Paleozoic rocks (Permian to Mississippian)-Siltstone, sandstone, conglomerate, limestone, and chert

Paleozoic rocks (Permian to Mississippian)-

Conglomerate and limestone; upper plate of Tertiary low-angle fault

\section{DEFORMATION OF MESOZOIC AND EOCENE AGE}

Evidence for oldest post-Paleozoic tectonism was the formation in the Early Triassic of a deep marine basin in the Adobe Range area and the accumulation in it of bouldery

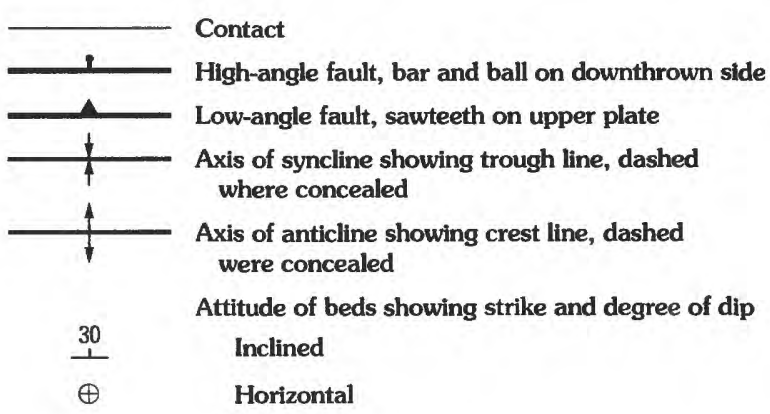

debris flows of material eroded from exposed Permian shelf rocks.

The apparently total lack of Middle Triassic to lower Upper Jurassic marine or continental deposits in the Elko area suggests elevation or filling of the Early Triassic basin and subsequent external drainage during at least the latter part of that interval. The sedimentary record of nearby areas 
provides no evidence that the region was elevated much above sea level. The nearest exposure of Upper Triassic and Lower Jurassic sedimentary rocks is in east-central Nevada (Stewart, 1980), about $65 \mathrm{mi}(104 \mathrm{~km})$ southeast of Elko. Those beds, which overlie marine inner shelf limestone of Early Triassic age, consist of thin strata of, from base to top, pebble conglomerate, red beds of shale and siltstone, and eolian crossbedded sandstone. This sequence is similar to the Upper Triassic Chinle Formation and Lower Jurassic Navajo Sandstone of southern Nevada and much of Utah. Such formations characterize cratonal to inner shelf environments and suggest regional stability, not proximity to active tectonism. This apparent interval of middle Mesozoic tectonic tranquillity was interrupted abruptly, in the Elko area, in the latest Jurassic by an episode of siliceous intrusive and extrusive igneous activity, deposition of conglomeratic sediments, folding, and low-angle faulting that continued intermittently through the Eocene.

\section{Northern Adobe Range}

Lower Triassic, Permian, and Silurian strata of the northern Adobe Range were stacked over parautochthonous Mississippian and older units by low-angle faulting and folded to form the southeast-verging Adobe Range Syncline and Garamendi Anticline (fig. 2) (Ketner and Smith, 1974; Ketner, 1987; Ketner and Ross, 1990). The steeply inclined limbs of these folds were overridden by plates composed mainly of lower Paleozoic deep-water strata such as the Ordovician Vinini Formation. These latter faults are classed as contractional because they juxtapose overriding deepwater facies with contemporaneous shelf facies. The latter are not exposed but are shown to be present by exploratory oil wells drilled immediately adjacent to the Adobe Range. Folds and low-angle faults of the northern Adobe Range were transected unconformably by the Eocene Elko Formation.

The Elko Formation, however, which is exposed extensively around the northeastern and northern parts of the Adobe Range, is itself somewhat warped but not detached from the underlying Paleozoic rocks. In general, it dips radially away from the range apparently reflecting domal upwarping in post-Eocene time. At one locality basal beds of the Elko Formation dip $50^{\circ}$, but stratigraphically higher beds are less steeply inclined. Unconformably overlying ignimbrite, probably equivalent to the Indian Well Formation, is less deformed and is almost horizontal in the northernmost areas of exposure as indicated by outcrop patterns in relation to topography. Thus, the northern Adobe Range displays a clear record of intense folding and low-angle faulting within the Middle Triassic to early Eocene interval, followed by an episode of erosion, deposition of lacustrine sediments, and greatly diminished deformation in the late Eocene.

\section{Peko Hills}

In the Peko Hills shallow-water Devonian to Permian strata were strongly folded with southeast vergence and overridden by Mississippian and Permian deep-water strata on low-angle faults (Ketner and Evans, 1988). The telescoping of contrasting facies of Permian rocks confirms the contractional nature of the deformation. Triassic rocks identical with those of the northern Adobe Range were involved in the low-angle faulting. The Miocene Humboldt Formation is undeformed. The time of faulting and folding in the Peko Hills, on the basis of local evidence, can therefore be determined to be within the Middle Triassic-Miocene interval.

\section{Northern Cortez Mountains}

Upper(?) Jurassic sedimentary beds of the Big Pole Formation in its main exposure and at its type locality strike northeast and dip steeply northwestward (fig. 3) (Muffler, 1964, plate 1). The northeast-trending strike of the Big Pole Formation was unaffected by the discordant intrusion of a large granitic stock, except directly adjacent to the contact, indicating that the structure of the Big Pole probably was not caused by forcible igneous intrusion. The Cortez Mountains are part of a tilted Basin-Range fault block. If the $10^{\circ}-20^{\circ}$ east tilt of the range, as determined from the dips of Cretaceous, Miocene, and younger beds in the vicinity of figure 3 , were restored to horizontal, the dip of bedding in the Big Pole Formation would be steeper, generally approaching vertical and in places overturned. The Sod House Tuff and Frenchie Creek Rhyolite may be less deformed than the Big Pole Formation, although scarcity of sedimentary beds in these primarily volcanic units makes their attitudes somewhat uncertain. The Cretaceous Newark Canyon Formation in the vicinity of the Big Pole Formation is almost undeformed, and beds would be horizontal on subtraction of Tertiary tilt.

Thus, in the Cortez Mountains, structural evidence indicates that an episode of strong folding or tilting began in the Late Jurassic and subsided before the early Late Cretaceous. Deposition of coarse, heterogeneous conglomerate near Eureka in the late Early Cretaceous provides additional, indirect evidence of deformation during the same time interval.

\section{Piñon Range}

Much of the deformation in the Piñon Range is Mesozoic to Tertiary in age (Ketner and Smith, 1974; Smith and Ketner, 1977). The Adobe Range Syncline of Triassic to Eocene age extends to the northern Piñon Range, and throughout the range upper Paleozoic rocks are strongly deformed. The 
onset of post-Paleozoic folding and low-angle faulting in the Piñon Range is difficult to determine and can be estimated only from the age of coarse conglomerate derived from Paleozoic rocks in the vicinity. The oldest of these is early Late Cretaceous in age.

Much of the deformation took place in the late Eocene, as indicated by the structural relations near Emigrant Spring. There, Mississippian units and the unconformably overlying Elko Formation have been folded in the form of an asymmetrical, south-plunging syncline with east vergence (fig. 4) (Smith and Ketner, 1978; Server and Solomon, 1983). An anticline and thrust fault, both subparallel with the Emigrant Spring Syncline, are exposed in the Paleozoic units just west of the syncline. The Emigrant Spring Syncline plunges southward and disappears beneath the almost undeformed Indian Well Formation. In the Emigrant Spring area, the age of deformation is therefore probably late Eocene, close to the Eocene-Oligocene boundary as fixed by the ages of the youngest radiometrically dated bed of the Elko Formation (37.1 $\pm 1.0 \mathrm{Ma}, \mathrm{K}-\mathrm{Ar}$; Solomon and others, 1979) and the oldest dated bed of the Indian Well (37.6 $\pm 1.3 \mathrm{Ma}, \mathrm{K}-\mathrm{Ar}$; Smith and Ketner, 1976)

\section{Elko Hills}

In the Elko Hills, Lower Mississippian to Lower Pennsylvanian(?) siliceous deep-water turbidites were thrust over Lower Permian shelf rocks (Ketner, 1990). This contractional event is interpreted to have taken place before eruption of the Eocene rhyodacite of Elko Mountain and deposition of the Eocene Elko Formation because the upper plate is known to lie only on Permian rocks. Subsequently, the rhyodacite of Elko Mountain, Elko Formation, and underlying Paleozoic units were folded and partially overridden by a plate or plates of Paleozoic rocks (fig. 5) (Ketner, 1990). Folds include a well-defined anticline, a parallel, poorly defined anticline, and a poorly defined syncline. The exposed length of the better defined anticline is about $10 \mathrm{mi}(16 \mathrm{~km})$. Trends of the fold axes are generally about $\mathrm{N} .45^{\circ} \mathrm{E}$., almost parallel with trends of fold axes in Paleozoic rocks of the Peko Hills $10 \mathrm{mi}$ $(16 \mathrm{~km})$ to the northeast and with the main trend of the axis of the Adobe Range Syncline $5 \mathrm{mi}(8 \mathrm{~km})$ to the northwest (fig. 1). Tuffaceous beds near the southwest corner of the mapped area (fig. 5) assigned to the uppermost Eocene and Oligocene Indian Well Formation were interpreted by Solomon and Moore (1982b) to be tilted, but not folded, as a result of extensional faulting. The upper Miocene Humboldt Formation, which crops out east and west of the Elko Hills, is undeformed.

On the northeastern flank of Elko Mountain (fig. 5) a klippe, composed of the lower part of the Pennsylvanian and Permian Strathearn Formation, overlies Permian beds that dip $20^{\circ}-30^{\circ}$ and beds of the Elko Formation that dip as much as $45^{\circ}$. The low-angle fault on which the Strathearn lies and beds within the Strathearn dip very gently to the northeast. On the northern flank of the mountain two closely spaced klippen composed of the Mississippian and Lower Pennsylvanian Diamond Peak Formation overlie Permian beds and the Eocene rhyodacite of Elko Mountain. The fault on which the Diamond Peak lies is irregular but, in general, dips gently to the northwest. Interpolation of fault attitudes among the three allochthonous plates suggests that if the plates were once connected the fault on which they lie was only slightly arched and discordantly spanned the Elko Mountain folds. Thus, structural evidence in the Elko Hills suggests that folding took place after deposition of the Eocene Elko Formation and the rhyodacite of Elko Mountain, certainly before deposition of the upper Miocene Humboldt Formation, and probably before eruption of the uppermost Eocene and Oligocene Indian Well Formation. Low-angle faulting took place probably between the Early Permian and middle Eocene and again after deposition and folding of the Elko Formation and eruption of the rhyodacite of Elko Mountain.

\section{FOLDS AND LOW-ANGLE FAULTS IN THE ELKO AREA: CONTRACTIONAL OR EXTENSIONAL?}

Admittedly, some folds and low-angle faults, considered by themselves, may be hard to classify as contractional or extensional; however, compatible associations of numerous and varied structural features, typical of either shortened or extended terranes generally, can be classified more confidently. Typical post-Early Triassic, pre-Basin and Range structural features of the area of this report are large-scale folds verging toward the southeast quadrant, older over younger low-angle faults related to major folds, and tectonic juxtaposition of contrasting facies. Each of these features is typical of shortened terranes, but juxtaposition of contrasting facies constitutes the best evidence that the fault system and related folds are primarily contractional. Extensional faults cannot juxtapose contrasting facies but, rather, tend to spread them farther apart. Although Late Tertiary Basin and Range faults are pervasive in the region, structures typical of terranes that were highly extended in the mid-Tertiary, such as extremely rotated fault blocks, younger over older low-angle faults with omission of strata, and greatly attenuated strata, are not prominent in the area of this report. Younger over older faults are present in the northern Adobe Range, but the dominant features of that area are large-scale folds broken by older over younger faults and telescoping of facies. Steeply dipping strata in Jurassic rocks of the Cortez Mountains could be interpreted as expressions of a tilted fault block, but gently inclined strata in the northernmost exposures suggest that a fold axis is present. 
The origin of large-scale folds and older over younger, low-angle faults involving beds as young as Eocene is especially subject to controversy because the age of those structures approaches that of mid-Tertiary extensional structures well documented in many parts of Nevada. Moreover, Eocene lake deposits in the area can reasonably be interpreted to have been deposited under extensional conditions (Vandervoort and Schmitt, 1990). The large-scale folds in Eocene strata in the Piñon Range and the Elko Hills are here interpreted, however, as probable contractional features because they belong to a family of east- to northeasttrending, southeast-verging folds that, in nearby ranges, are demonstrably contractional. In addition, large-scale folds such as those affecting Eocene strata in the area are the normal expression of compression and are simply less likely to have formed under tensional conditions. The older over younger fault or faults in the northern Elko Hills could be an expression of either compression or tension. We favor the former but leave a final resolution of this uncertainty to future studies.

\section{COMPARISON WITH THE IDAHO- WYOMING-UTAH THRUST BELT}

Initial thrust faulting in various sectors of the IdahoWyoming-Utah Thrust Belt began in the latest Jurassic (Armstrong and Oriel, 1965; Oriel and Armstrong, 1966; Wiltschko and Dorr, 1983) or the late Early Cretaceous (Bohannon, 1983; Heller and others, 1986; Villien and Kligfield, 1986). Thrusting ended in the Paleocene (Villien and Kligfield, 1986) or the early Eocene (Armstrong and Oriel, 1965; Oriel and Armstrong, 1966; Wiltschko and Dorr, 1983). Principal pulses, determined by the ages of the principal conglomeratic deposits, were in the latest Jurassic, Late Cretaceous, Paleocene, and early Eocene (Wiltschko and Dorr, 1983) or the Early Cretaceous, Late Cretaceous, and Paleocene (Villien and Kligfield, 1986). The prevailing concept that the ages of conglomeratic deposits reflect ages of principal thrust pulses has been questioned by Blair and Bilodeau (1988), but, even if their belief that the ages of finer grained foreland sediments (rather than conglomerate) more accurately date the orogenic pulses is correct, the interval of contractional deformation in the thrust belt remains essentially within the latest Jurassic to early Eocene interval. Thus, the interval of faulting and folding in the Elko area, here interpreted as primarily contractional, corresponds roughly to contractional deformation in the thrust belt.

\section{REFERENCES CITED}

Armstrong, F.C., and Oriel, S.S., 1965, Tectonic development of the Idaho-Wyoming thrust belt: American Association of Petroleum Geologists Bulletin v. 49, no. 11, p. 1847-1866.
Armstrong, R.L., 1963, Geochronology and geology of the eastern Great Basin in Nevada and Utah; New Haven, Conn., Yale University, Ph.D. thesis, 202 p.

Biglow, C.C., 1986, Stratigraphy and sedimentology of the Cretaceous Newark Canyon Formation in the Cortez Mountains, north-central Nevada: Cheney, Eastern Washington University, M.S. thesis, $123 \mathrm{p}$.

Blair, T.C., and Bilodeau, W.L., 1988, Development of tectonic cyclothems in rift, pull-apart, and foreland basins-Sedimentary response to episodic tectonism: Geology, v. 16, p. 517-520.

Bohannon, R.G., 1983, Mesozoic and Cenozoic tectonic development of the Muddy, North Muddy, and northern Black Mountains, Clark County, Nevada, in Miller, D.M., Todd, V.R., and Howard, K.A., eds., Tectonic and stratigraphic studies in the eastern Great Basin: Geological Society of America Memoir 157, p. 125-148.

Clark, T.M., 1985, The structure and Precambrian to Cambrian stratigraphy in the Bull Run Mountains, Elko County, Nevada: University of California, Davis, M.S. thesis, 137 p.

Coats, R.R., 1987, Geology of Elko County, Nevada: Nevada Bureau of Mines and Geology Bulletin 101, 112 p.

Coats, R.R., and Riva, J., 1983, Overlapping overthrust belts of late Paleozoic and Mesozoic ages, northern Elko County, Nevada, in Miller, D.M., Todd, V.R., and Howard, K.A., eds., Tectonic and stratigraphic studies in the eastern Great Basin: Geological Society of America Memoir 157, p. 305-327.

Ehman, K.D., 1985, Paleozoic stratigraphy and tectonics of the Bull Run Mountains, Elko County, northern Nevada: University of California, Davis, Ph.D. dissertation, 174 p.

Fouch, T.D., Hanley, J.H., and Forester, R.M., 1979, Preliminary correlation of Cretaceous and Paleogene lacustrine and related nonmarine sedimentary and volcanic rocks in parts of the eastern Great Basin of Nevada and Utah, in Armentrout, J.M., Cole, M.R., and TerBest, Harry, eds., Cenozoic paleogeography of the western United States, Pacific Coast Paleogeography Symposium 3: Pacific Section, Society of Economic Paleontologists and Mineralogists, p. 97-111.

Gilluly, James, and Masursky, Harold, 1965, Geology of the Cortez quadrangle, Nevada: U.S. Geological Survey Bulletin 1175 , $117 \mathrm{p}$.

Harland, W.B., Armstrong, R.L., Cox, A.V., Craig, L.E., Smith, A.G., and Smith, D.G., 1990, A geologic time scale 1989: Cambridge, England, Cambridge University Press, 262 p.

Harland, W.B., Smith, A.G., and Wilcock, Bruce, eds., 1964, The Phanerozoic time-scale-A symposium dedicated to Professor Arthur Holmes: Geological Society of London Quarterly Journal, Supplement, v. 120, 458 p.

Heller, P.L., Bowdler, S.S., Chambers, H.P., Coogan, J.C., Hagen, E.S., Shuster, M.W., Winslow, N.S., and Lawton, T.F., 1986, Time of initial thrusting in the Sevier orogenic belt, IdahoWyoming and Utah: Geology, v. 14, p. 388-391.

Jaeger, K.B., 1987, Structural geology and stratigraphy of the Elko Hills, Elko County, Nevada: Laramie, University of Wyoming, M.S. thesis, $70 \mathrm{p}$.

Ketner, K.B., 1984, Recent studies indicate that major structures in northeastern Nevada and the Golconda thrust in north-central Nevada are of Jurassic or Cretaceous age: Geology, v. 12, p. 483-486.

1987, Post-Early Triassic, pre-middle Eocene folds and thrust faults, northern Adobe Range, Nevada: Cordilleran Section, Geological Society of America Centennial Field Guide, p. 91-94. 
1990, Geologic map of the Elko Hills, Elko County, Nevada: U.S. Geological Survey Miscellaneous Investigations Map I-2082, scale 1:24,000.

Ketner, K.B., and Evans, J.G., 1988, Geologic map of the Peko Hills, Elko County, Nevada: U.S. Geological Survey Miscellaneous Investigations Map I-1902, scale 1:24,000.

Ketner, K.B., and Ross, R.J., Jr., 1990, Preliminary geologic map of the northern Adobe Range, Elko County, Nevada: U.S. Geological Survey Miscellaneous Investigations Map I-2081, scale 1:24,000.

Ketner, K.B., and Smith, J.F., Jr., 1974, Folds and overthrusts of Late Jurassic or Early Cretaceous age in northern Nevada: U.S. Geological Survey Journal of Research, v. 2, no. 4, p. 417-419.

1982, Mid-Paleozoic age of the Roberts thrust unsettled by new data from northern Nevada: Geology, v. 10, p. 298-303.

Little, T.A., 1987, Stratigraphy and structure of metamorphosed upper Paleozoic rocks near Mountain City, Nevada: Geological Society of America Bulletin, v. 98, p. 1-17.

Muffler, L.J.P., 1964, Geology of the Frenchie Creek quadrangle, north-central Nevada: U.S. Geological Survey Bulletin 1179, $99 \mathrm{p}$.

Nolan, T.B., Merriam, C.W., and Williams, J.S., 1956, The stratigraphic section in the vicinity of Eureka, Nevada: U.S. Geological Survey Professional Paper 276, 76 p.

Oriel, S.S., and Armstrong, F.C., 1966, Times of thrusting in IdahoWyoming thrust belt; reply: American Association of Petroleum Geologists Bulletin, v. 50, p. 2614-2621.

Server, G.T., Jr., and Solomon, B.J., 1983, Geology and oil shale deposits of the Elko Formation, Piñon Range, Elko County, Nevada: U.S. Geological Survey Miscellaneous Field Studies Map MF-1546, scale 1:24,000.

Smith, J.F., Jr., and Ketner, K.B., 1976, Stratigraphy of post-Paleozoic rocks and summary of resources in the Carlin- Piñon Range area, Nevada: U.S. Geological Survey Professional Paper 867-B, p. B1-B48.

1977, Tectonic events since early Paleozoic in the Carlin-Piñon Range area, Nevada: U.S. Geological Survey Professional Paper 867-C, 18 p.
1978, Geologic map of the Carlin-Piñon Range area, Elko and Eureka Counties, Nevada: U.S. Geological Survey Miscellaneous Investigations Map I-1028, scale 1:62,500.

Solomon, B.J., McKee, E.H., and Andersen, D.W., 1979, Stratigraphy and depositional environments of Paleogene rocks near Elko, Nevada, in Armentrout, J.M., Cole, M.R., and TerBest, Harry, Jr., eds., Cenozoic paleogeography of the westem United States, Pacific Coast Paleogeography Symposium 3: Pacific Section, Society of Economic Paleontologists and Mineralogists, p. 75-88.

Solomon, B.J., and Moore, S.W., 1982a, Geologic map and oil shale deposits of the Elko West quadrangle, Elko County, Nevada: U.S. Geological Survey Miscellaneous Field Studies Map MF-1410, scale 1:24,000.

1982b, Geologic map and oil shale deposits of the Elko East quadrangle, Elko County, Nevada: U.S. Geological Survey Miscellaneous Field Studies Map MF-1421, scale 1:24,000.

Stewart, J.H., 1980, Geology of Nevada: Nevada Bureau of Mines and Geology Special Publication 4, $136 \mathrm{p}$.

Stewart, J.H., and Carlson, J.E., 1978, Geologic map of Nevada: U.S. Geological Survey, scale 1:500,000.

Thorman, C.H., Ketner, K.B., Brooks, W.E., Snee, L.W., and Zimmerman, R.A., 1991, Late Mesozoic-Cenozoic tectonics in northeastern Nevada, in Raines, G.L., Lisle, R.E., Schafer, R.W., and Wilkinson, W.H., eds., Geology and ore deposits of the Great Basin: Geological Society of Nevada Symposium Proceedings, v. 2, p. 25-45.

Vandervoort, D.S., and Schmitt, J.G., 1990, Cretaceous to early Tertiary paleogeography in the hinterland of the Sevier thrust belt, east-central Nevada: Geology, v. 18, p. 567-570.

Villien, Alain, and Kligfield, R.M., 1986, Thrusting and synorogenic sedimentation in central Utah, in Peterson, J.A., ed., Paleotectonics and sedimentation in the Rocky Mountain region, United States: American Association of Petroleum Geologists Memoir 41, p. 281-307.

Wiltschko D.V., and Dorr, J.A., Jr., 1983, Timing of deformation in overthrust belt and foreland of Idaho, Wyoming, and Utah: American Association of Petroleum Geologists Bulletin, v. 67 , no. 8, p. 1304-1322. 


\section{SELECTED SERIES OF U.S. GEOLOGICAL SURVEY PUBLICATIONS}

\section{Periodicals}

Earthquakes \& Volcanoes (issued bimonthly).

Preliminary Determination of Epicenters (issued monthly).

\section{Technical Books and Reports}

Professional Papers are mainly comprehensive scientific reports of wide and lasting interest and importance to professional scientists and engineers. Included are reports on the results of resource studies and of topographic, hydrologic, and geologic investigations. They also include collections of related papers addressing different aspects of a single scientific topic.

Bulletins contain significant data and interpretations that are of lasting scientific interest but are generally more limited in scope or geographic coverage than Professional Papers. They include the results of resource studies and of geologic and topographic investigations; as well as collections of short papers related to a specific topic.

Water-Supply Papers are comprehensive reports that present significant interpretive results of hydrologic investigations of wide interest to professional geologists, hydrologists, and engineers. The series covers investigations in all phases of hydrology, including hydrology, availability of water, quality of water, and use of water.

Circulars present administrative information or important scientific information of wide popular interest in a format designed for distribution at no cost to the public. Information is usually of short-term interest.

Water-Resources Investigations Reports are papers of an interpretive nature made available to the public outside the formal USGS publications series. Copies are reproduced on request unlike formal USGS publications, and they are also available for public inspection at depositories indicated in USGS catalogs.

Open-File Reports include unpublished manuscript reports, maps, and other material that are made available for public consultation at depositories. They are a nonpermanent form of publication that maybe cited in other publications as sources of information.

\section{Maps}

Geologic Quadrangle Maps are multicolor geologic maps on topographic bases in $71 / 2$ - or 15-minute quadrangle formats (scales mainly $1: 24,000$ or $1: 62,500)$ showing bedrock, surficial, or engineering geology. Maps generally include brief texts; some maps include structure and columnar sections only.

Geophysical Investigations Maps are on topographic or planimetric bases at various scales, they show results of surveys using geophysical techniques, such as gravity, magnetic, seismic, or radioactivity, which reflect subsurface structures that are of economic or geologic significance. Many maps include correlations with the geology.

Miscellaneous Investigations Series Maps are on planimetric or topographic bases of regular and irregular areas at various scales; they present a wide variety of format and subject matter. The series also includes 7 1/2-minute quadrangle photogeologic maps on planimetric bases which show geology as interpreted from aerial photographs. The series also includes maps of Mars and the Moon.
Coal Investigations Maps are geologic maps on topographic or planimetric bases at various scales showing bedrock or surficial geology, stratigraphy, and structural relations in certain coal-resource areas.

Oil and Gas Investigations Charts show stratigraphic information for certain oil and gas fields and other areas having petroleum potential.

Miscellaneous Field Studies Maps are multicolor or black-andwhite maps on topographic or planimetric bases on quadrangle or irregular areas at various scales. Pre-1971 maps show bedrock geology in relation to specific mining or mineral-deposit problems; post-1971 maps are primarily black-and-white maps on various subjects such as environmental studies or wilderness mineral investigations.

Hydrologic Investigations Atlases are multicolored or black-andwhite maps on topographic or planimetric bases presenting a wide range of geohydrologic data of both regular and irregular areas; the principal scale is $1: 24,000$, and regional studies are at $1: 250,000$ scale or smaller.

\section{Catalogs}

Permanent catalogs, as well as some others, giving comprehensive. listings of U.S. Geological Survey publications are available under the conditions indicated below from the U.S. Geological Survey, Books anc' Open-File Reports Sales, Box 25286, Denver, CO 80225. (See lates: Price and Availability List.)

"Publications of the Geological Survey, 1879-1961" may be purchased by mail and over the counter in paperback book form and as a set. microfiche.

"Publications of the Geological Survey, 1962-1970" may be purchased by mail and over the counter in paperback book form and as a se* of microfiche.

"Publications of the U.S. Geological Survey, 1971-1981" may be. purchased by mail and over the counter in paperback book form (twr volumes, publications listing and index) and as a set of microfiche.

Supplements for 1982, 1983, 1984, 1985, 1986, and for subsequent years since the last permanent catalog may be purchased by mai" and over the counter in paperback book form.

State catalogs, "List of U.S. Geological Survey Geologic and Water-Supply Reports and Maps For (State)," may be purchased by mail and over the counter in paperback booklet form only.

"Price and Availability List of U.S. Geological Survey Publications," issued annually, is available free of charge in paperback bookle form only.

Selected copies of a monthly catalog "New Publications of the U.S. Geological Survey" is available free of charge by mail or may be obtained over the counter in paperback booklet form only. Those wishing a free subscription to the monthly catalog "New Publications of the U.S. Geological Survey" should write to the U.S. Geological Survey, $582 \mathrm{Na}$ tional Center, Reston, VA 22092.

Note.-Prices of Government publications listed in older catalogs. announcements, and publications may be incorrect. Therefore, the price: charged may differ from the prices in catalogs, announcements, and pub. lications. 


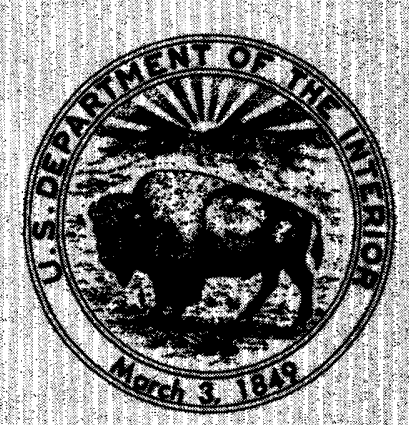

